\title{
Extracorporeal Membrane Oxygenation in COVID-19 Treatment: a Systematic Literature Review
}

Tatiana Farias de Oliveira ; Carlos Alberto de Oliveira Rocha ${ }^{1}$; Aisla Graciele Galdino dos Santos ${ }^{1}$; Luiz Carlos Francelino Silva Junior'; Saulo Henrique Salgueiro de Aquino'; Euclides José Oliveira da Cunha ${ }^{1}$; Rafaela Campos Alcântara'; Rodrigo da Rosa Mesquita '; Gabriel Monteiro Arnozo ${ }^{1}$; Fernanda Mayara Santos Santana'; Etvaldo Rodrigues da Silva Filho'; Carlos Dornels Freire de Souza', PhD

DOI: $10.21470 / 1678-9741-2020-0397$

\begin{abstract}
Introduction: The present study intends to systematically review the literature on the use of extracorporeal membrane oxygenation (ECMO) in patients with coronavirus disease 2019 (COVID-19).

Methods: The research was carried out according to the recommendations of the Preferred Reporting Items for Systematic Reviews and Meta-Analyzes (PRISMA). Studies were selected from PubMed/MEDLINE and LILACS databases between December 2019 and May 17 2020, using the descriptors "ECMO AND COVID-19", "Extracorporeal Membrane Oxygenation AND COVID-19", "ECLS AND COVID-19", and "Extracorporeal Life Support AND COVID-19". Exclusion criteria were government epidemiological bulletins, comments, literature reviews, and articles without full access to content.

Results: Two hundred and thirty-three scientific productions were found, however only $\mathbf{1 8}$ did not met the exclusion criteria and
\end{abstract}

could be included in this study, amouting to a total of 911 patients $-624(68.5 \%)$ men, 261 (28.6\%) women, and 26 (2.8\%) without sex information. The mean age of the patients was 53.7 years. ECMO was necessary in $274(30.1 \%)$ people (200 [73\%] submitted to venovenous ECMO, nine [3.3\%] to veno-arterial ECMO, and seven [2.5\%] moved between these two types or needed a more specific ECMO according to the disease prognosis). Five studies did not specify the type of ECMO used, amounting $57(20.8 \%)$ patients. Five patients (1.8\%) were discharged, $77(28.1 \%)$ died, 125 (45.6\%) remained hospitalized until publication time of their respective studies, and 67 patients $(24.4 \%)$ had no outcome information.

Conclusion: It is evident that more research, covering larger populations, must be carried out in order to clearly elucidate the role of ECMO in the treatment of COVID-19.

Keywords: Extracorporeal Membrane Oxygenation. Coronavirus Infections. COVID-19. Patient Discharge.

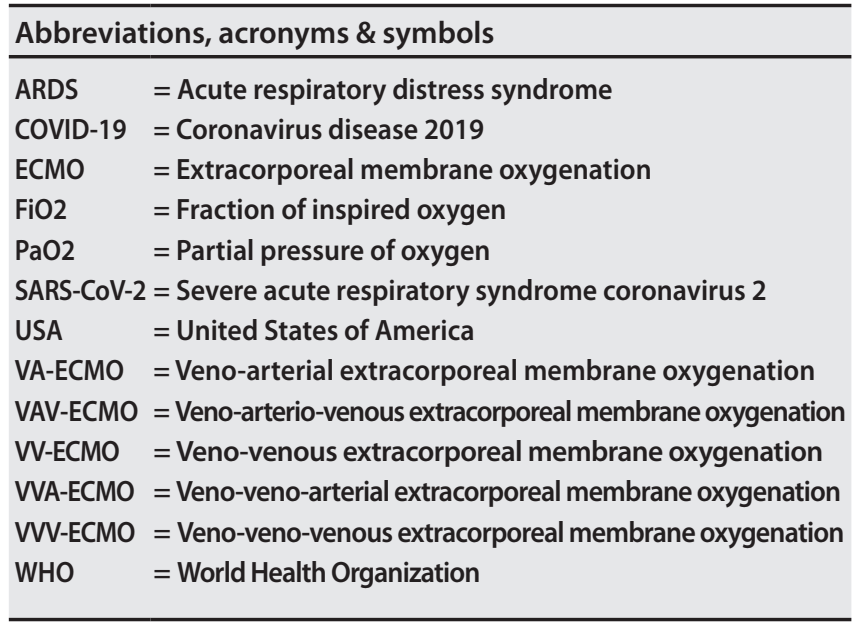

'Department of Medicine, Universidade Federal de Alagoas, Arapiraca, Alagoas, Brazil.

This study was carried out at the Department of Medicine, Universidade Federal de Alagoas, Arapiraca, Alagoas, Brazil.

\section{INTRODUCTION}

Coronavirus disease 2019 (COVID-19), a disease caused by a new type of coronavirus, the severe acute respiratory syndrome coronavirus 2 (SARS-CoV-2), is being considered cause of the most important health crisis of the last hundred years ${ }^{[1]}$. Originating in the People's Republic of China, the disease quickly spread to all continents. On March 11 2020, the World Health Organization (WHO) declared a pandemic status ${ }^{[2]}$.

In June 12 2020, more than 7.4 million people were infected and 400,000 deaths had occurred from the disease worldwide. Behind the United States of America (USA) alone, with two million cases, Brazil occupied, on that date, the second position in the ranking of countries with more cases of COVID-19, with about 850 thousand cases. In terms of number of deaths, USA remains in the lead, accounting for 115,000 deaths ${ }^{[3]}$.

Correspondence Address:

Tatiana Farias de Oliveira

iD https://orcid.org/0000-0002-4186-6287

Universidade Federal de Alagoas, Campus Arapiraca

Rodovia AL-115, Bom Sucesso, Arapiraca, Alagoas, Brazil - Zip Code: 57309-005

E-mail: tatiiana.fariias@gmail.com 
SARS-CoV-2 infection can lead to the development of acute respiratory distress syndrome $(A R D S)^{[4]}$. Approximately $14 \%$ of COVID-19 cases are serious and 5\% are critical[5]. In such cases, therapy includes protective pulmonary mechanical ventilation, neuromuscular blockade, higher positive end-expiratory pressure, pulmonary recruitment techniques, and prone positioning. When conventional therapy fails, extracorporeal membrane oxygenation (ECMO) can be considered as an alternative in certain patients ${ }^{[6]}$.

In ECMO treatment, there are two basic methods that can be used: veno-venous (V-ECMO) or veno-arterial (VA-ECMO) [7]. Regarding to COVID-19 respiratory complications, W-ECMO is the recommended form ${ }^{[6]}$. Thus, this study aims to review the literature on the use of this therapeutic strategy in patients with COVID-19.

\section{METHODS}

\section{Data Sources and Search Strategies}

This is a systematic review conducted according to the Preferred Reporting Items for Systematic Reviews and MetaAnalyzes, or PRISMA ${ }^{[8]}$, recommendations.

For this review, studies involving patients with COVID-19 were used. Studies published in the PubMed/MEDLINE and LILACS databases were screened between December 2019 and May 17 2020, using the descriptors "ECMO AND COVID-19", "Extracorporeal Membrane Oxygenation AND COVID-19", "ECLS AND COVID-19", and "Extracorporeal Life Support AND COVID-19". In addition, a manual search was carried out for references cited in the articles.

\section{Research Variables}

The following variables were researched: country of study, study population, sex (male and female), use of ECMO, type of ECMO used in the treatment of patients with COVID-19, main outcomes, and conclusions/recommendations.

\section{Eligibility criteria}

We included letters to the editor, clinical trials, cohorts, cross-sectional studies, clinical cases, and case series studies (published and pre-print). Government epidemiological bulletins, comments, literature reviews, articles without full access to content, and studies in animals were excluded.

\section{Selection of Studies}

The search was carried out by four independent researchers. After this stage, three researchers independently performed the following steps: 1) reading the title and summary to identify potential eligible studies; 2) reading the full text; 3) collecting ECMO data and setting up the database. The analysis was independently conducted by two other researchers. The divergences were analyzed and resolved by consensus.

The included studies were submitted to a qualitative analysis using the Risk Of Bias In Non-randomized Studies of Interventions, or ROBINS- ${ }^{[9]}$, which is a recommended tool to assess the risk of bias in non-randomized studies included in systematic reviews.

\section{Data Extraction}

For data extraction, the researchers created a database. At this stage, the database was mounted. The data was entered by a first investigator and subsequently checked by a second investigator on the team. The systematization/analysis of the data was conducted by two other independent researchers.

\section{RESULTS}

Initially, 233 scientific productions were found in the researched databases. After the successive stages of analysis, only 18 articles fit the objective of this study, pointing to ECMO as one of the resources in the treatment of COVID-19 (Figure 1): Europe ${ }^{[4]}$ (1 study, 333 patients), People's Republic of China ${ }^{[2,6,10,11,12]}$ (5 studies, 385 patients), Japan ${ }^{[13,14,15,16]}$ (4 studies, 98 patients), USA ${ }^{[17,18,19]}$ (3 studies, 43 patients), Spain ${ }^{[20]}$ (1 study, 48 patients), Italy ${ }^{[21]}$ (1 study, 1591 patients), and Switzerland ${ }^{[22]}$ (1 study, 1 patient).

The surveys total 911 patients confirmed with COVID-19, $68.5 \%(n=624)$ males and $28.6 \%(n=261)$ females; there was no sex information about $2.8 \%(n=26)$ of the patients. The mean age of patients in studies $[1,2,4,6,10,11,12,13,14,15,16,17,19,21,22,26]$ that reported this data was 53,7 years. and Japan was the country with the oldest patients, with the highest reported age being 81 years and the lowest, 16 years.

ECMO was necessary as a resource in those patients whose health status was severe/critical, totaling 274 (30.1\%) people (Table 1). Regarding the type of ECMO,73\% ( $n=200)$ of the patients underwent V-ECMO. Among the others, nine individuals (3.3\%) required $V A-E C M O$ and seven patients (2.5\%) moved from one type to another according to the disease prognosis, or needed a more specific type of ECMO such as veno-veno-venous ECMO, veno-arterio-venous ECMO, or veno-veno-arterial ECMO. Five studies $^{[2,8,12,13,10]}$ did not specify the type of ECMO used to treat their patients (57 [20.8\%] patients) (Table 1).

Regarding the outcome related to the use of ECMO, concerning the 274 patients who used the therapeutic resource, five ( $n=1.8 \%$ ) were discharged, 125 (45.6\%) remained hospitalized until the publication date of the respective study, and there was no outcome information about 67 patients $(n=24.4 \%)$ (Table 1). Five studies ${ }^{[2,4,6,15,18]}(\mathrm{n}=219)$ reported deaths during treatment, totaling 77 patients (35.2\%), among which, two studies ${ }^{[2,6]}$ developed in the People's Republic of China had the highest mortality rate.

When analyzing the risk of bias in different domains studies, it is noticed that there is a predominance of serious risk of bias due to confounding, to selection of participants, and in measurement of outcomes, however, the studies presented low risk of bias due to deviations from the intended interventios and moderate risk on what concerns to bias in classification of interventions and selection of the reported result. Bias due to missing data presented moderate, low, and no information risk proportional between selected papers. The overall risk of bias of all selected articles was classified as serious (Figure 2). 


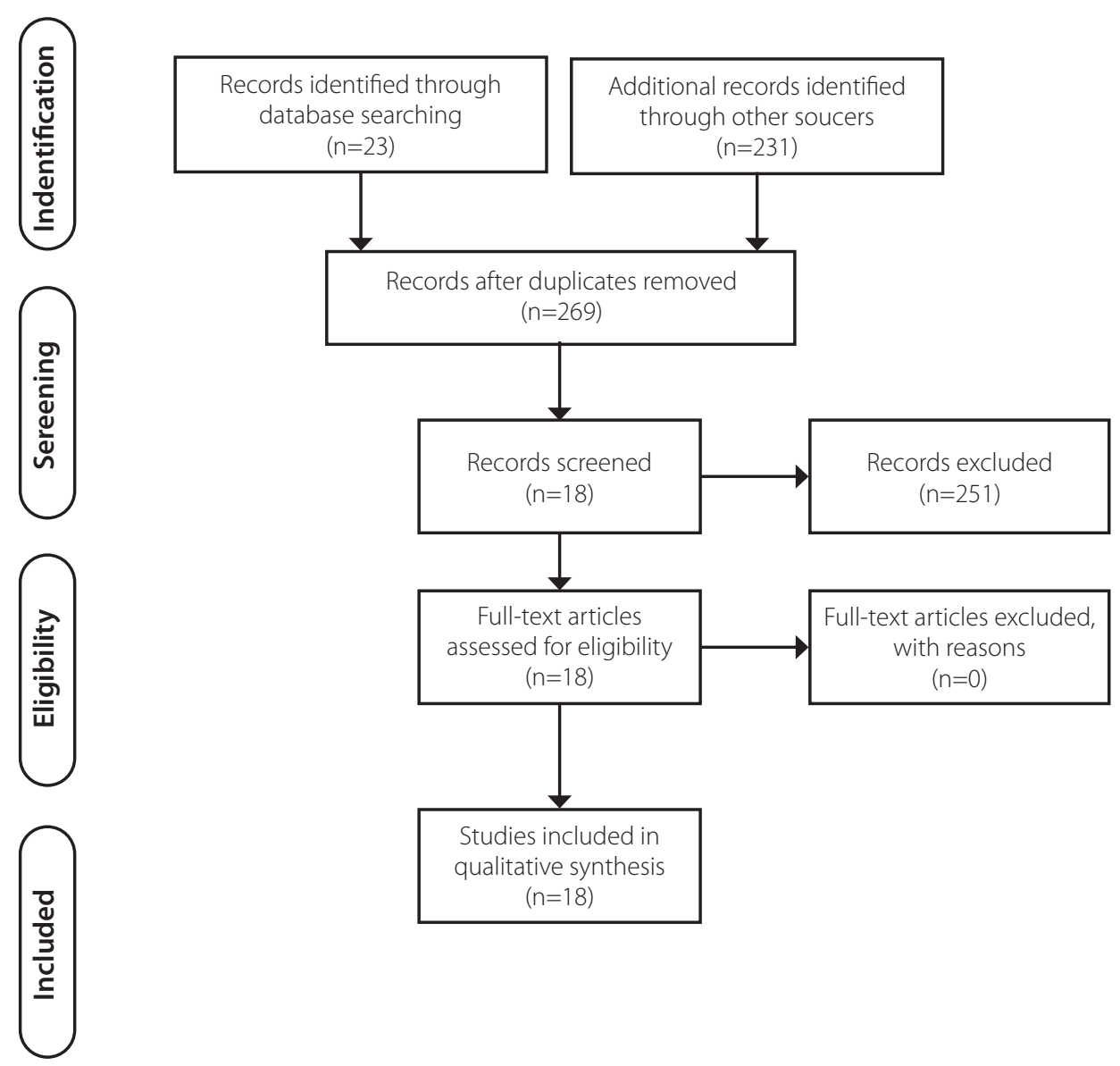

Fig. 1 - Flowchart of studies selection, 2020.

Table 1. Characterization of the articles included in the study ( $n=18), 2020$.

\begin{tabular}{|c|c|c|c|c|c|c|c|c|}
\hline \multirow{2}{*}{ Study } & \multirow{2}{*}{$\begin{array}{c}\text { Total } \\
\mathrm{N}\end{array}$} & \multirow{2}{*}{ Age (years) } & \multicolumn{2}{|c|}{ Sex } & \multirow{2}{*}{$\begin{array}{l}\text { Use of } \\
\text { ECMO }\end{array}$} & \multirow{2}{*}{ Type of ECMO } & \multirow{2}{*}{ Main outcome } & \multirow{2}{*}{$\begin{array}{l}\text { Conclusion/ } \\
\text { Suggestions }\end{array}$} \\
\hline & & & Men & Women & & & & \\
\hline $\begin{array}{l}\text { Hartman ME et } \\
{\text { al. } .^{[1]}}\end{array}$ & 1 & 44 & $1(100 \%)$ & - & $1(100 \%)$ & W-ECMO & Hospital discharge. & $\begin{array}{l}\text { The study suggests } \\
\text { caution with the } \\
\text { applicability of ECMO } \\
\text { based on the experience } \\
\text { of a single patient. }\end{array}$ \\
\hline Case report & & & & & & & & \\
\hline Case series & 12 & $\begin{array}{c}\text { Mean age: } 50.9 \\
(35-76)\end{array}$ & $\begin{array}{c}11 \\
(91.7 \%)\end{array}$ & 1 (8.3\%) & $12(100 \%)$ & Not specified & $\begin{array}{l}3(25 \%) \text { patients } \\
\text { evolved without } \\
\text { ECMO; } 4 \text { (33.3\%) } \\
\text { patients still alive } \\
\text { with ECMO, but } 2 \\
\text { in a coma; } 5(41.7 \%) \\
\text { patients died. }\end{array}$ & $\begin{array}{l}\text { The paper suggests } \\
\text { further studies on the } \\
\text { use of ECMO in patients } \\
\text { with COVID-19, and } \\
\text { caution is needed to } \\
\text { recommend ECMO to } \\
\text { patients with COVID-19 } \\
\text { in critical condition }\end{array}$ \\
\hline
\end{tabular}




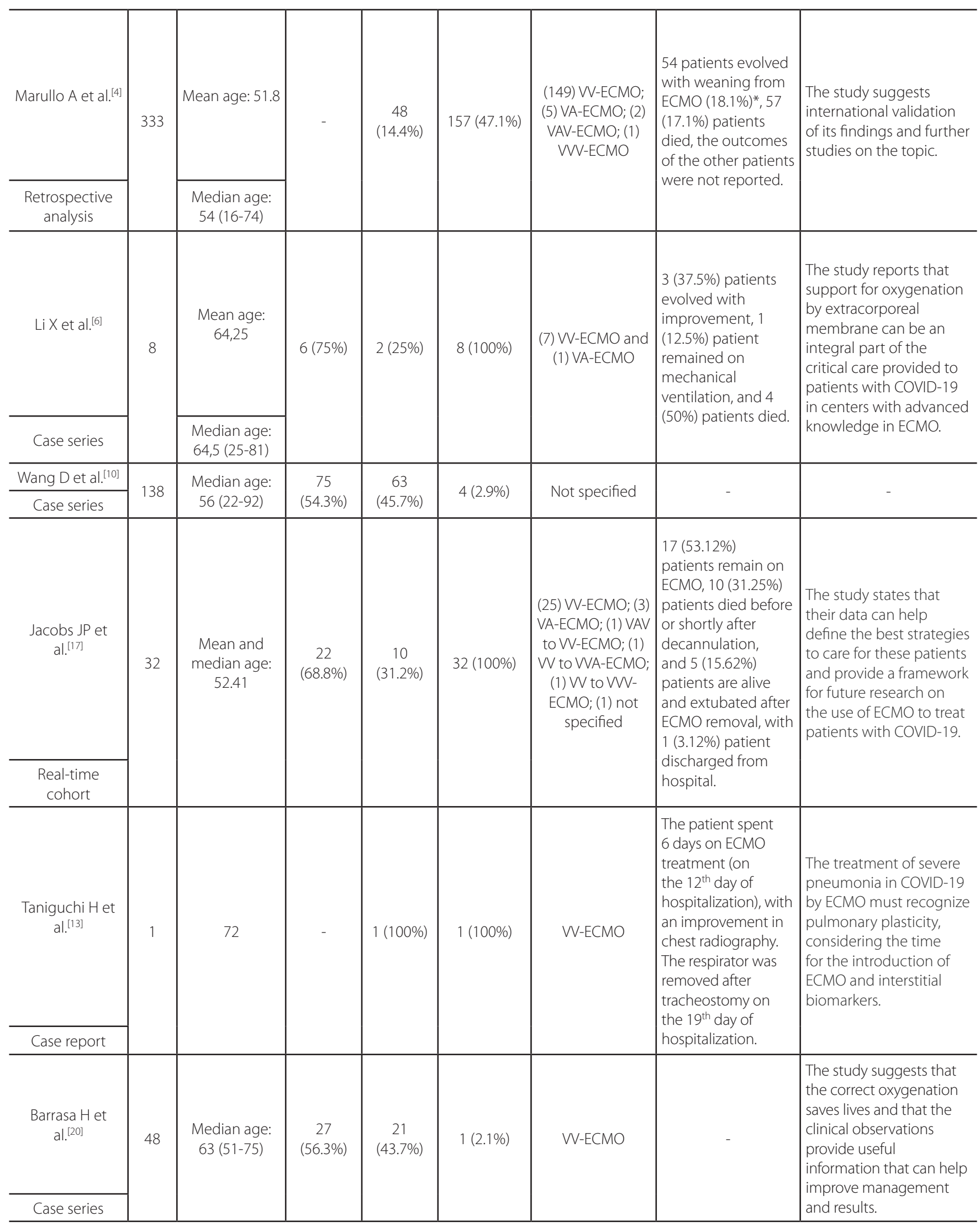




\begin{tabular}{|c|c|c|c|c|c|c|c|c|}
\hline $\begin{array}{c}\text { Sultan I et al. }{ }^{[18]} \\
\text { Case series }\end{array}$ & 10 & $31-62$ & 7 (70\%) & $3(30 \%)$ & 10 (100\%) & W-ECMO & $\begin{array}{l}2 \text { (20\%) patients } \\
\text { were successfully } \\
\text { released from ECMO } \\
\text { support, } 1(10 \%) \\
\text { patient is currently } \\
\text { undergoing } \\
\text { weaning, and } \\
1 \text { patient (10\%) } \\
\text { died after } 9 \text { days } \\
\text { of ECMO due } \\
\text { to multiorgan } \\
\text { dysfunction. All } \\
\text { other patients } \\
\text { remain on ECMO. }\end{array}$ & $\begin{array}{l}\text { The paper reports that its } \\
\text { data can guide intensive } \\
\text { care management and } \\
\text { resource allocation of } \\
\text { the intensive care unit } \\
\text { and ECMO infrastructure, } \\
\text { in addition to being an } \\
\text { attempt to characterize } \\
\text { the patient population } \\
\text { using ECMO to help } \\
\text { establish selection } \\
\text { criteria. }\end{array}$ \\
\hline $\begin{array}{l}\text { Firstenberg MS } \\
\text { et al. }{ }^{[19]}\end{array}$ & 1 & 51 & - & $1(100 \%)$ & 1 (100\%) & W-ECMO & $\begin{array}{l}\text { Patient was } \\
\text { extubated after } 11 \\
\text { days of treatment, } \\
\text { being discharged } \\
\text { after other } 11 \text { days } \\
\text { of extubation. }\end{array}$ & $\begin{array}{l}\text { The study suggests } \\
\text { timely referral to a } \\
\text { tertiary center with } \\
\text { established experience } \\
\text { and standardized } \\
\text { ECMO protocols, if } \\
\text { it is considered a } \\
\text { treatment for COVID-19. } \\
\text { It also suggests future } \\
\text { prospective multicenter } \\
\text { studies to validate its } \\
\text { findings in a larger } \\
\text { cohort of patients. }\end{array}$ \\
\hline $\begin{array}{c}\text { Zhan WQ et } \\
\text { al. } .^{[11]}\end{array}$ & 1 & 54 & $1(100 \%)$ & - & 1 (100\%) & W-ECMO & $\begin{array}{l}\text { Patient left ECMO } 5 \\
\text { days after treatment } \\
\text { with normal vital } \\
\text { signs, but remained } \\
\text { on mechanical } \\
\text { ventilation for } \\
\text { another } 10 \text { days. } \\
\text { The patient received } \\
\text { oxygen inhalation } \\
\text { for another } 6 \text { days, } \\
\text { being discharged } \\
\text { from the hospital on } \\
\text { February } 24 .\end{array}$ & $\begin{array}{l}\text { The study strongly } \\
\text { recommends ECMO } \\
\text { treatment since the } \\
\text { beginning of the illness } \\
\text { in critical patients with } \\
\text { COVID-19 and warns that } \\
\text { the patient's clotting } \\
\text { function and blood gases } \\
\text { need to be monitored } \\
\text { regularly to decide how } \\
\text { long to use ECMO. }\end{array}$ \\
\hline $\begin{array}{c}\text { Nakamura K et } \\
\text { al. }^{[14]}\end{array}$ & 1 & 45 & $1(100 \%)$ & - & 1 (100\%) & Not specified & $\begin{array}{l}\text { The patient was } \\
\text { decannulated after } \\
11 \text { days using ECMO } \\
\text { and was discharged } \\
12 \text { days later. }\end{array}$ & - \\
\hline $\begin{array}{l}\text { Bemtgen et } \\
a^{\left[l_{.}^{[26]}\right.}\end{array}$ & 1 & 52 & $1(100 \%)$ & - & 1 (100\%) & VA-WV ECMO & $\begin{array}{l}\text { ECMO continued } \\
\text { to function, even } \\
\text { after } 24 \text { days of } \\
\text { treatment. }\end{array}$ & - \\
\hline Giani et al. ${ }^{[21]}$ & 1 & 66 & $1(100 \%)$ & - & 1 (100\%) & W-ECMO & - & - \\
\hline Case report & & & & & & & & \\
\hline
\end{tabular}




\begin{tabular}{|c|c|c|c|c|c|c|c|c|}
\hline $\begin{array}{l}\text { Japan ECMsOne. } \\
\text { [15] }\end{array}$ & 26 & $\begin{array}{c}\text { Mean age: } 71 \\
(45-81)^{* *}\end{array}$ & - & - & $26(100 \%)$ & Not specified & $\begin{array}{l}16 \text { (62\%) patients } \\
\text { were weaned, } 6 \\
\text { (26\%) patients } \\
\text { were extubated } \\
\text { and referred for } \\
\text { rehabilitation, and } \\
10 \text { (38\%) patients } \\
\text { remained on ECMO. } \\
\text { The available data } \\
\text { from the first } 14 \\
\text { cases demonstrated } \\
\text { that the median } \\
\text { number of days } \\
\text { between intubation } \\
\text { and ECMO was } 3 \\
\text { days (range 0-9 }\end{array}$ & $\begin{array}{l}\text { The study concludes that } \\
\text { patients who presented } \\
\text { a preserved lung } \\
\text { compliance phenotype } \\
\text { were probably favored } \\
\text { by the use of ECMO and } \\
\text { indicates the adoption } \\
\text { of a real-time discussion } \\
\text { platform to guide the } \\
\text { use of ECMO. Finally, } \\
\text { it is suggested further } \\
\text { research to classify the } \\
\text { ideal use of ECMO in } \\
\text { patients with COVID-19. }\end{array}$ \\
\hline $\begin{array}{c}\text { Cross-sectional } \\
\text { study }\end{array}$ & & & & & & & days). & \\
\hline Case series & 70 & $\begin{array}{c}\text { Mean age: } 67 \\
(54-72)\end{array}$ & $\begin{array}{c}47 \\
(67.1 \%)\end{array}$ & $\begin{array}{c}23 \\
(32.9 \%)\end{array}$ & $2(2.85 \%)$ & W-ECMO & $\begin{array}{l}\text { Patients were } \\
\text { successfully treated } \\
\text { and survived at } \\
\text { the end of the } \\
\text { observation period: } \\
1 \text { patient was } \\
\text { extubated on day } \\
13 \text { of ventilation } \\
\text { and the other one } \\
\text { was intubated for } \\
23 \text { days using } \mathrm{V} \text { - } \\
\text { ECMO. }\end{array}$ & - \\
\hline $\begin{array}{c}\text { Cross-sectional } \\
\text { study }\end{array}$ & 226 & $\begin{array}{c}\text { Mean age: } 64 \\
(57-70)\end{array}$ & $\begin{array}{c}139 \\
(61.5 \%)\end{array}$ & $\begin{array}{c}87 \\
(38.5 \%)\end{array}$ & 14 (6.2\%) & Not specified & - & - \\
\hline $\begin{array}{c}\begin{array}{c}\text { Schmiady et } \\
\text { al. }{ }^{[22]}\end{array} \\
\text { Case series }\end{array}$ & 1 & 54 & - & 1 (100\%) & 1 (100\%) & W-ECMO & - & - \\
\hline
\end{tabular}

COVID-19=coronavirus disease 2019; ECMO=extracorporeal membrane oxygenation; $V A-E C M O=$ veno-arterial ECMO; $V A V-E C M O=v e n o-a r t e r i o-$ venous $\mathrm{ECMO}$; $\mathrm{V}$ - $E C M O=$ =veno-venous $\mathrm{ECMO}$; $\mathrm{VA}-\mathrm{ECMO}=$ veno-veno-arterial $\mathrm{ECMO}$; $\mathrm{VV}$-ECMO=veno-veno-venous ECMO

*The study brings these adjusted data for smaller denominators due to incomplete reports.

**The study brings the available data from the first 14 cases.

\section{DISCUSSION}

Most patients with COVID-19 have mild symptoms and evolve to cure of the disease. However, some of them progress to a severe state of the disease, developing dyspnoea and hypoxemia about a week after onset. Such patients can rapidly progress to ARDS and, later, to multiple organ failure or even death ${ }^{[10]}$.

WHO and the Centers for Disease Control and Prevention, or $C D C$, through the publication of guidelines, indicate the possibility of treatment by ECMO in patients in severe/critical condition, with respiratory failure and cardiac involvement, whose conventional treatment is not being promising ${ }^{[17]}$.

ECMO is indicated in patients with refractory hypoxemia with a partial pressure of oxygen $\left(\mathrm{PaO}_{2}\right) /$ fraction of inspired oxygen $\left(\mathrm{FiO}_{2}\right)<50 \mathrm{mmHg}$ for three hours or a $\mathrm{PaO}_{2} / \mathrm{FiO}_{2}<80 \mathrm{mmHg}$ for $>6$ hours ${ }^{[23]}$. Severe and refractory hypoxemia is an event associated with mortality in over $95 \%$ of patients. In this scenario, conventional mechanical ventilation is not able to promote minimal blood oxygenation compatible with life. At this time, the 


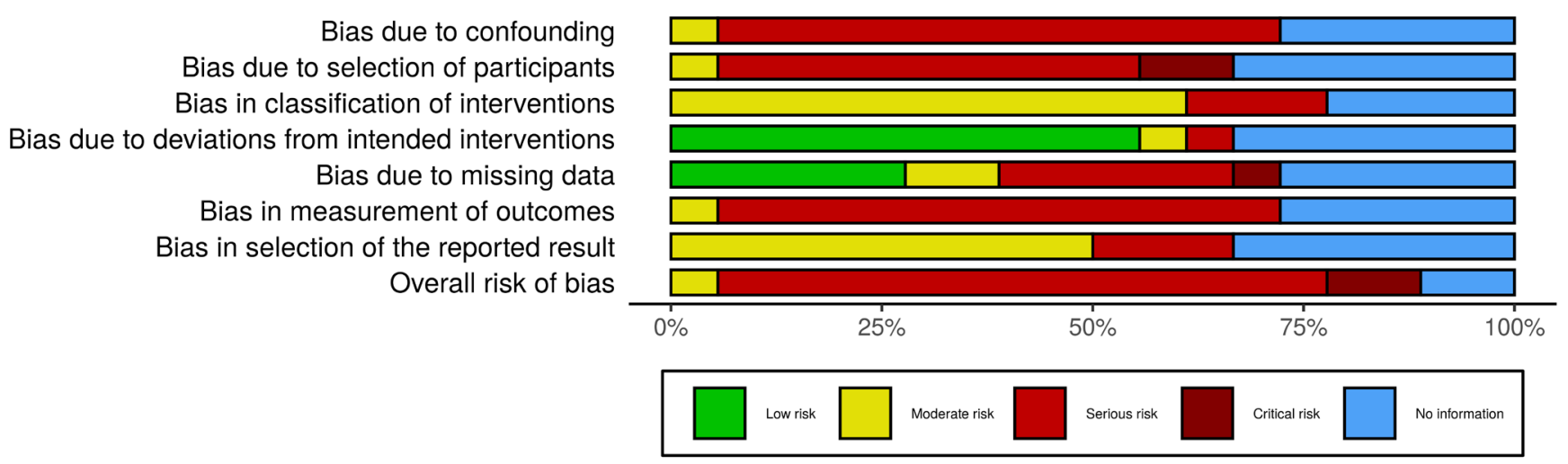

Fig. 2 - Risk of bias in studies.

extracorporeal oxygenation technique (ECMO) can be used until the lungs recover and regain their basic function ${ }^{[22]}$.

In this review, less than half of the analyzed patients used ECMO. In fact, it is an intensive therapy whose priority is given to a specific group of patients: younger patients with a relatively low prevalence of comorbidities and with an acceptable probability of reversing the pulmonary failure typical of these patients ${ }^{[25]}$ Thus, an adequate clinical judgment and an understanding of the risk-benefit relationship are important to identify when ECMO may be effective ${ }^{[13]}$

In addition, some factors must be observed, such as old age, comorbidities that portend a poor prognosis (diabetes, heart disease, obesity, among others), and, especially, if patients have hemorrhage in the central nervous system, underlying terminal diseases, or evidence of multisystem organ failure ${ }^{[5]}$.

A fact verified in this study was that the majority of patients who needed ECMO were submitted to the venous type. In fact, except for VA-ECMO cannulation in emergency situations, as in the case of cardiopulmonary resuscitation, patients are placed on $\mathrm{V}$-ECMO, in order to correct the hypoxia resulting from the lung failure caused by the virus, having considered that the low oxygen content could progress quickly, leading to multiple organ failure ${ }^{[6]}$.

Some patients, during $\mathrm{ECMO}$, may receive antivirals, antibacterial agents, steroids, immunoglobulins, chloroquine, vasoconstrictor agents, or even other medications as complementary treatment. Other concomitant therapies are also possible, such as renal replacement ${ }^{[20,18]}$. Everything will depend on what problems the patient may present as well as the choice of which other treatment will be ideal to help in the recovery of the patient.

It is noteworthy that the role of ECMO in the treatment of the disease caused by this new virus remains uncertain and, in the meantime, new research by several authors is always suggested $[2,5,13,18,19]$. From this perspective, the position among researchers may be controversial, because while some authors tend to be more pessimistic when observing high mortality rates with this type of treatment ${ }^{[2,19]}$, including reporting septic shock and multiple organ failure ${ }^{[2]}$, others suggest that it may play an important role and aid to those in the critical state of ARDS due to COVID-19 $9^{[4,6,11]}$. Such facts become more evident when assessing the risk of bias in studies.

It should also be noted that the therapeutic modality of extracorporeal ventilation is still not widespread. This scenario may be due to the fact that ECMO is an expensive technology that consumes many resources, which may make it impossible for several countries affected by COVID-19 to pay for it ${ }^{[6]}$. Another important point is that it must be carried out in experienced centers, with qualified professionals, and a multidisciplinary approach ${ }^{[6,25]}$

\section{Limitations}

The main limitation of this study was the small number of papers that addressed the use of ECMO treatment in the current pandemic.

\section{CONCLUSION}

Based on the above, it is evident that more studies, covering larger populations, should be carried out with regard to the use of ECMO in COVID-19 patients, mainly because it is an alternative to the conventional failed treatment of some critical patients. It can also be seen that with new studies, the mechanisms that involve the disease and death of patients due to COVID-19 could be better evidenced, mainly in critical condition, in order to elucidate the role of ECMO in the treatment of patients affected by COVID-19.

\section{No financial support.} No conflict of interest. 


\section{Authors' roles \& responsibilities}

TFO Substantial contributions to the conception or design of the work; or the acquisition, analysis, or interpretation of data for the work; drafting the work or revising it critically for important intellectual content; final approval of the version to be published

CAOR Substantial contributions to the conception or design of the work; or the acquisition, analysis, or interpretation of data for the work; drafting the work or revising it critically for important intellectual content; final approval of the version to be published

AGGS Substantial contributions to the conception or design of the work; or the acquisition, analysis, or interpretation of data for the work; drafting the work or revising it critically for important intellectual content; final approval of the version to be published

LCFSJ Substantial contributions to the acquisition, analysis, or interpretation of data for the work; translation and critical review of the work; final approval of the version to be published

SHSA Contributions to the acquisition, analysis, or interpretation of data for the work; revising the work; final approval of the version to be published

EJOC Contributions to the acquisition, analysis, or interpretation of data for the work; revising the work; final approval of the version to be published

RCA Contributions to the acquisition, analysis, or interpretation

RRM of data for the work; revising the work; final approval of the version to be published

Contributions to the acquisition, analysis, or interpretation

GMA of data for the work; revising the work; final approval of the version to be published

Contributions to the acquisition, analysis, or interpretation

FMSS of data for the work; revising the work; final approval of the version to be published

Contributions to the acquisition, analysis, or interpretation

ERSF of data for the work; revising the work; final approval of the version to be published

Contributions to the acquisition, analysis, or interpretation

CDFS of data for the work; revising the work; final approval of the version to be published

Substantial contributions to the conception or design of the work; or the acquisition, analysis, or interpretation of data for the work; drafting the work or revising it critically for important intellectual contetn; final approval of the version to be published

\section{REFERENCES}

1. Hartman ME, Hernandez RA, Patel K, Wagner TE, Trinh T, Lipke AB, et al. COVID-19 respiratory failure: targeting inflammation on W-ECMO support. ASAIO J. 2020;66(6):603-6. doi:10.1097/MAT.0000000000001177.

2. Zeng Y, Cai Z, Xianyu Y, Yang BX, Song T, Yan Q. Prognosis when using extracorporeal membrane oxygenation (ECMO) for critically ill COVID-19 patients in China: a retrospective case series. Crit Care. 2020;24(1):148. doi:10.1186/s13054-020-2840-8.

3. World Health Organization. Coronavirus disease (COVID-19). Situation Report; 147. Geneva:WHO; 2020 Jun 15 [cited 2020 Jun 15]. Available from: https://www.who.int/docs/default-source/coronaviruse/situationreports/20200615-covid-19-sitrep-147.pdf?sfvrsn=2497a605_2

4. Marullo AG, Cavarretta E, Biondi-Zoccai G, Mancone M, Peruzzi M, Piscioneri $F$, et al. Extracorporeal membrane oxygenation for critically ill patients with coronavirus-associated disease 2019: an updated perspective of the European experience. Minerva Cardioangiol. 2020. doi:10.23736/S0026-4725.20.05328-1.

5. Wu Z, McGoogan JM. Characteristics of and important lessons from the Coronavirus disease 2019 (COVID-19) outbreak in China: summary of a report of 72314 cases from the Chinese center for disease control and prevention. JAMA. 2020;323(13):1239-42. doi:10.1001/jama.2020.2648.

6. LiX, Guo Z, Li B, Zhang X, Tian R, Wu W, et al. Extracorporeal membrane oxygenation for Coronavirus disease 2019 in Shanghai, China. ASAIO J. 2020;66(5):475-81. doi:10.1097/MAT.0000000000001172.

7. Smereka J, Puslecki M, Ruetzler K, Filipiak KJ, Jaguszewski M, Ladny JR, et al. Extracorporeal membrane oxygenation in COVID-19. Cardiol J. 2020;27(2):216-7. doi:10.5603/CJ.a2020.0053.

8. Moher D, Liberati A, Tetzlaff J, Altman DG; PRISMA Group. Preferred reporting items for systematic reviews and meta-analyses: the PRISMA statement. PLoS Med. 2009;6(7):e1000097. doi:10.1371/journal. pmed.1000097.

9. Sterne JA, Hernán MA, Reeves BC, Savović J, Berkman ND, Viswanathan $M$, et al. ROBINS-I: a tool for assessing risk of bias in non-randomised studies of interventions. BMJ. 2016;355:i4919. doi: 10.1136/bmj.i4919.

10. Wang D, Hu B, Hu C, Zhu F, Liu X, Zhang J, et al. Clinical characteristics of 138 hospitalized patients with 2019 novel Coronavirus-infected pneumonia in Wuhan, China. JAMA. 2020;323(11):1061-9. doi:10.1001/ jama.2020.1585.

11. Zhan WQ, Li MD, Xu M, Lu YB. Successful treatment of COVID-19 using extracorporeal membrane oxygenation, a case report. Eur Rev Med Pharmacol Sci. 2020;24(6):3385-9. doi:10.26355/eurrev_202003_20705.

12. Yu Y, Xu D, Fu S, Zhang J, Yang X, Xu L, et al. Patients with COVID-19 in 19 ICUs in Wuhan, China: a cross-sectional study. Crit Care. 2020;24(1):219. doi:10.1186/s13054-020-02939-x

13. Taniguchi H, Ogawa F, Honzawa H, Yamaguchi K, Niida S, Shinohara M, et al. Veno-venous extracorporeal membrane oxygenation for severe pneumonia: COVID-19 case in Japan. Acute Med Surg. 2020;7(1):e509. doi:10.1002/ams2.509.

14. Nakamura K, Hikone M, Shimizu H, Kuwahara Y, Tanabe M, Kobayashi $\mathrm{M}$, et al. A sporadic COVID-19 pneumonia treated with extracorporeal membrane oxygenation in Tokyo, Japan: a case report. J Infect Chemother. 2020;26(7):756-61. doi:10.1016/j.jiac.2020.03.018.

15. Japan ECMOnet for COVID-19. Nationwide system to centralize decisions around ECMO use for severe COVID-19 pneumonia in Japan (special correspondence). J Intensive Care. 2020;8:29. Erratum in: J Intensive Care. 2020;8:38. doi:10.1186/s40560-020-00445-4.

16. Kato H, Shimizu H, Shibue Y, Hosoda T, Iwabuchi K, Nagamine K, et al. Clinical course of 2019 novel coronavirus disease (COVID-19) in individuals present during the outbreak on the Diamond Princess cruise ship. J Infect Chemother. 2020;26(8):865-9. doi:10.1016/j.jiac.2020.05.005.

17. Jacobs JP, Stammers AH, St Louis J, Hayanga JWA, Firstenberg MS, Mongero LB, et al. Extracorporeal membrane oxygenation in the treatment of severe pulmonary and cardiac compromise in Coronavirus disease 2019: experience with 32 patients. ASAIO J. 2020;66(7):722-30. doi:10.1097/MAT.0000000000001185.

18. Sultan I, Habertheuer A, Usman AA, Kilic A, Gnall E, Friscia ME, et al. The role of extracorporeal life support for patients with COVID-19: preliminary results from a statewide experience. J Card Surg. 2020;35(7):1410-3. doi:10.1111/jocs.14583.

19. Firstenberg MS, Stahel PF, Hanna J, Kotaru C, Crossno J Jr, Forrester J. Successful COVID-19 rescue therapy by extra-corporeal membrane 
oxygenation (ECMO) for respiratory failure: a case report. Patient Saf Surg. 2020;14:20. doi:10.1186/s13037-020-00245-7.

20. Barrasa H, Rello J, Tejada S, Martín A, Balziskueta G, Vinuesa C, et al. SARS-CoV-2 in Spanish intensive care units: early experience with 15day survival in Vitoria. Anaesth Crit Care Pain Med. 2020;39(5):553-61. doi:10.1016/j.accpm.2020.04.001.

21. Giani M, Seminati D, Lucchini A, Foti G, Pagni F. Exuberant plasmocytosis in bronchoalveolar lavage specimen of the first patient requiring extracorporeal membrane oxygenation for SARS-CoV-2 in Europe. J Thorac Oncol. 2020;15(5):e65-6. doi:10.1016/j.jtho.2020.03.008.

22. Schmiady MO, Sromicki J, Kucher N, Ouda A. Successful percutaneous thrombectomy in a patient with COVID-19 pneumonia and acute pulmonary embolism supported by extracorporeal membrane oxygenation. Eur Heart J. 2020;41(32):3107. doi:10.1093/eurheartj/ ehaa403.

23. World Health Organization. Clinical management of severe acute respiratory infection when COVID-19 is suspected 2020. Geneva: WHO; 2020. Available from: https://www.who.int/publications-detail/ clinical-management-of-severe-acute-respiratory-infection-whennovel-coronavirus-(ncov)-infection-is-suspected.

24. Ministério da Saúde (BR). Uso da Oxigenação Extracorpórea no Suporte de Pacientes com Insuficiência Respiratória. Brasília (DF): Ministério da Saúde; 2015. Available from: http://conitec.gov.br/images/ Relatorios/2015/Relatorio_ECMO_final.pdf

25. World Health Organization. Clinical management of severe acute respiratory infection when novel coronavirus (2019-nCoV) infection is suspected: interim guidance. Geneva: WHO; 2020. Available from: https://apps.who.int/iris/bitstream/ handle/10665/330854/WHOnCoV-Clinical-2020.2-eng.pdf? sequence $=1$ \&isAllowed $=y \mathrm{WHO} / \mathrm{nCoV} /$ Clinical/2020.2

26. Bemtgen X, Krüger K, Supady A, Duerschmied D, Schibilsky D, Bamberg $F$, et al. First successful treatment of Coronavirus disease 2019 induced refractory cardiogenic plus vasoplegic shock by combination of percutaneous ventricular assist device and extracorporeal membrane oxygenation: a case report. ASAIO J. 2020;66(6):607-9. doi:10.1097/ MAT.0000000000001178. 